\title{
Mapping Development of Open Innovation Visually and Quantitatively: A Method of Bibliometrics Analysis
}

\author{
Weiguang Wang ${ }^{1}$ \& Jing Tang ${ }^{1}$ \\ ${ }^{1}$ Institute of Policy and Management, Chinese Academy of Sciences, Beijing, China \\ Correspondence: Jing Tang, Institute of Policy and Management, Chinese Academy of Sciences, No.15 \\ ZhongGuanCun BeiYiTiao Alley, Haidian District, Beijing 100190, China. Tel: 86-138-1038-2355. E-mail: \\ tangjing@casipm.ac.cn
}

Received: May 5, 2013 Accepted: June 13, 2013 Online Published: August 30, 2013

doi:10.5539/ass.v9n11p254 URL: http://dx.doi.org/10.5539/ass.v9n11p254

\begin{abstract}
Open innovation has become one of the hottest fields in innovation management. Although some reviews have been done to conclude the work of open innovation study, however, few of them were conducted quantitatively as well as visually. From a perspective of bibliometrics analysis, this article depicted a map of development of open innovation study with the help of CiteSpace II. Most important references and authors about open innovation study were picked out objectively according to their ranks and the visualization. The process of open innovation development was described and the newest topics in recent years are highlighted to help understand history of open innovation and do further study in this field. Also, according to the trend study, the current stage of open innovation study was estimated and the trends of recent future were forecasted.
\end{abstract}

Keywords: open innovation, visualization, bibliometrics analysis, CiteSpace II

\section{Introduction}

Open innovation has attracted quite a large amount of attention since its formal term was proposed (H. Chesbrough, 2003b; Terwiesch \& Ulrich, 2009; Von Hippel, 2005). Open innovation is coming with the concept of closed innovation which wastes some chances for development. The new thoughts of open innovation did promote power of innovation in helping firms to obtain new ways to get profit (H. Chesbrough, Vanhaverbeke, \& West, 2006; Henry Chesbrough \& Crowther, 2006). Actually, many companies achieved their new goals by adopting this open innovation strategy (H. Chesbrough, 2003a). However, researchers noted that open innovation existed early in the history and closed innovation was nearly not there (Linstone, 2010; Mowery, 2009). People use this tactic without abstracting concept of open innovation although some other ones like absorptive capacity (Cohen \& Levinthal, 1990) and complementary assets (Teece, 1986) were discussed that days. After H. Chesbrough (2003b) defined the term "open innovation" formally, hundreds of researchers started to study the nature of this phenomenon.

Although all researchers agree with the existence of open innovation, they have different understanding of its concept and use them respectively (Dahlander \& Gann, 2010; di Benedetto, 2010). It is natural to consider the state of open innovation study. More time is needed to develop a perfect system of open innovation concept. At the same time, more and more aspects of open innovation study were accepted by most researchers (Huizingh, 2011). Openness of individual firms is a continuum with varying degrees rather than a dichotomy (Dahlander $\&$ Gann, 2010) for many parts of the innovation process (O. Gassmann \& Enkel, 2004). Furthermore, open innovation was divided into inbound open innovation and outbound open innovation from the perspective of knowledge flow (Henry Chesbrough \& Crowther, 2006; Lichtenthaler, 2008a, 2008b; Lichtenthaler \& Lichtenthaler, 2009). When it comes to performance of open innovation, many things in innovation process are taken into account. Generally, costs like wasting time of managers, misleading of the strategy (Huizingh, 2011) and returns such as innovativeness, financial benefits (Cheng. \& Huizingh, 2010), identifying core competences (Rigby \& Zook, 2002) are shown to understand its performance. Laursen and Salter (2006) found the performance has a curve linear relationship with degree of open innovation due to some useless activities which are included into open innovation strategy. Also, Tomlinson (2010) found the strength of cooperation is more important than the existence of it. In this case, although open innovation is demonstrated to have the power to make firms perform quite well (H. Chesbrough, 2012; Lichtenthaler, 2007; Nagaoka \& Kwon, 2006), it needs 
more understanding about its negative impact (Dahlander \& Gann, 2010). The study also pays much attention to context of open innovation: internal characteristics and external environment (Oliver Gassmann, 2006). Internal characteristics includes employees (Harison \& Koski, 2010) openness (Bianchi, Cavaliere, Chiaroni, Frattini, \& Chiesa, 2011; Keupp \& Gassmann, 2009; Lee \& Xia, 2010; Lichtenthaler \& Ernst, 2009) and absorptive ability (Spithoven, Clarysse, \& Knockaert, 2010, 2011). External environment contains globalization, technology intensity, technology fusion, new business model and knowledge leveraging(O. Gassmann, Sandmeier, \& Wecht, 2006) most of which are all from traits of industry level(Christensen, Olesen, \& Kjaer, 2005; Lichtenthaler, 2008b; van de Vrande, de Jong, Vanhaverbeke, \& de Rochemont, 2009).

Although open innovation obtains some agreement among researchers, it is still a relative new field. And most of the studies focus on its nature rather than its powerful application in industries. Some work should be done to track trend of open innovation study to provide information about its history and future development. This paper mapped the history of open innovation study, found the hot topics in recent years and depicted the trend of open innovation study visually and quantitatively using bibliometrics analysis method with the help of Web of Science and CiteSpace II (Chen, 2004, 2006).

\section{Methodology}

This study used data got from Web of Science and CiteSpace II to analyze the trend of open innovation in the history and in the future. Although Web of Science only contains part of all the papers about open innovation, their references cover almost all the ones in this area. In this case, we can depict a map of the evolution of open innovation. In order to make sure papers collected from Web of Science can reflect the whole trend, Web of Knowledge which includes more ones was taken in to test it. We searched for all the articles and reviews in all years with a term "open innovation". Finally, we found 1564 records in Web of Science and 6028 ones in Web of Knowledge. Although they have quite different number, the number of cited papers is relatively the same. For the bibliometrics analysis, the useful ones are the top ones which indicates that papers that are out of Web of Science can hardly make negative effect on our analysis. At the same time, the trends of both search results are quite alike (see figure 1 to 4 ).

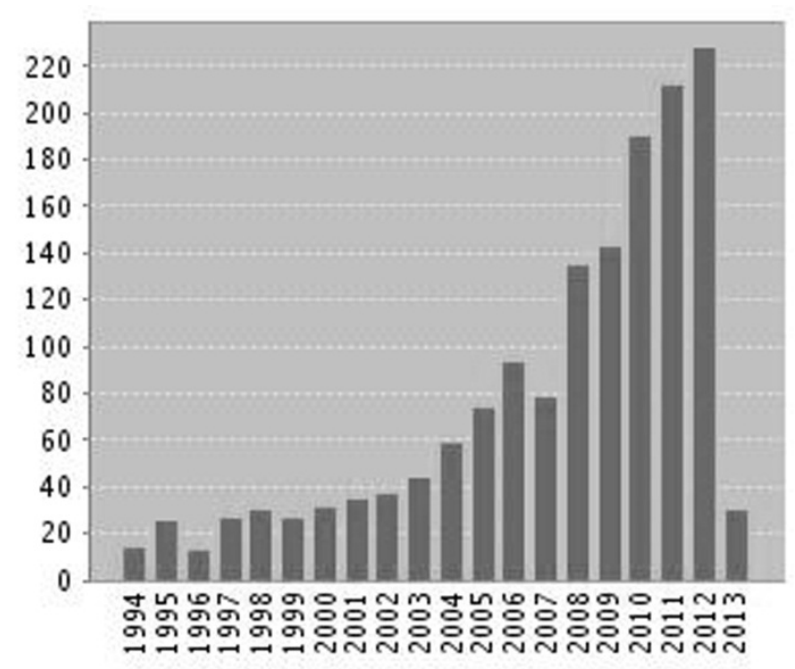

Figure 1. Published items each year in web of science 


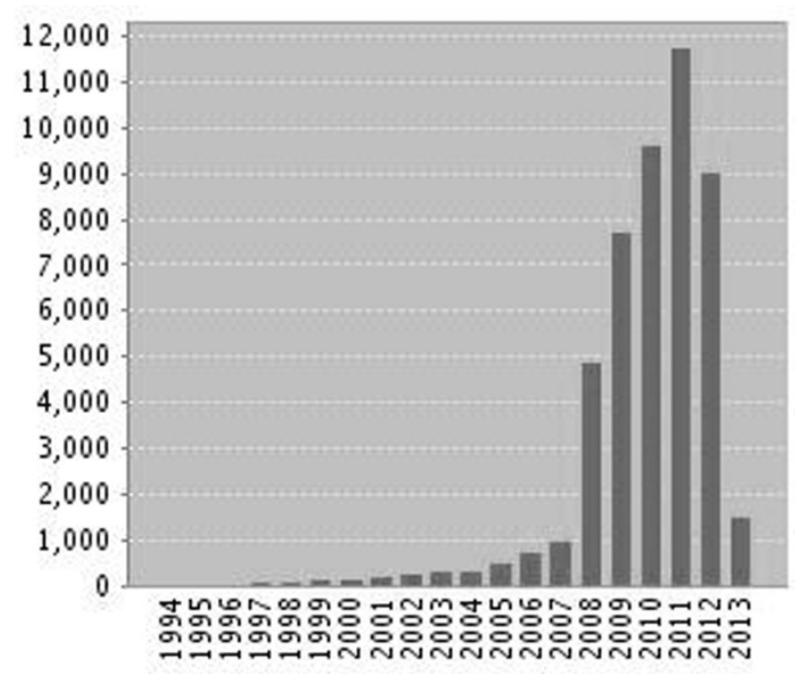

Figure 2. Citations each year in web of science

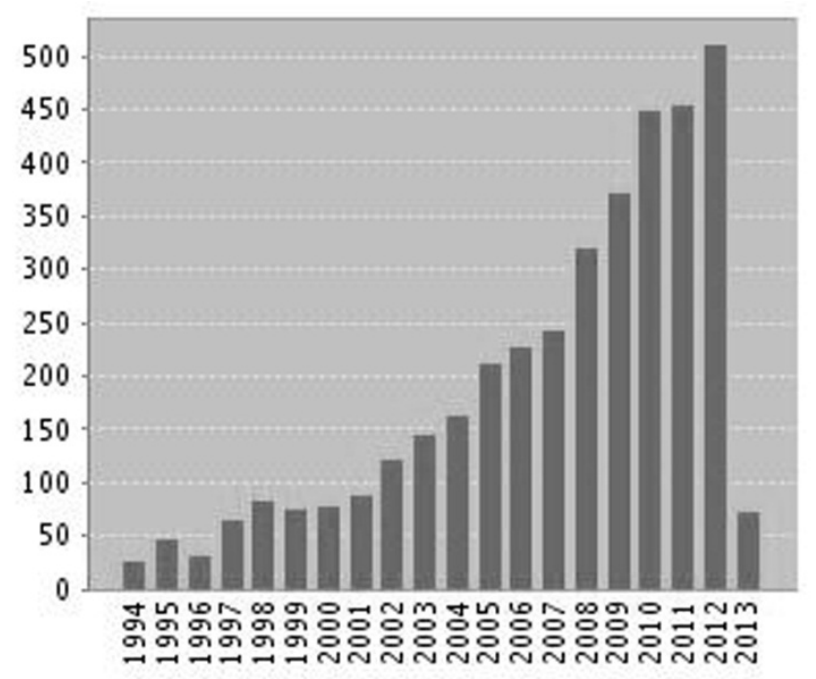

Figure 3. Published items each year in web of knowledge

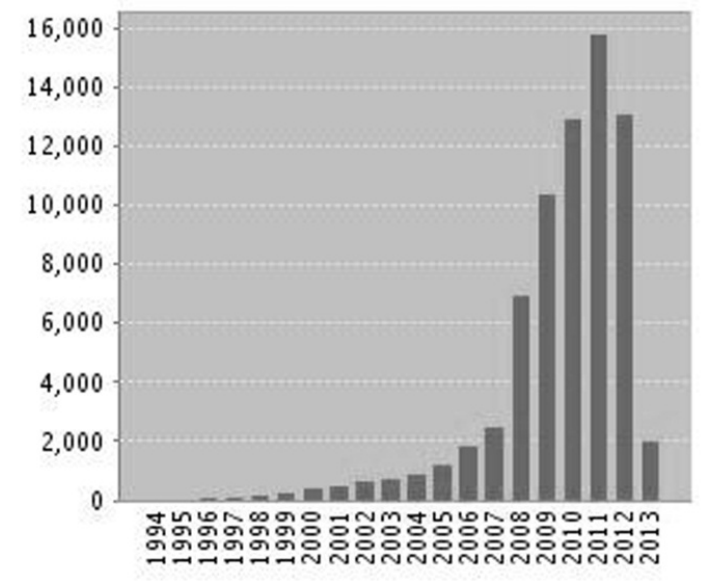

Figure 4. Citations each year in web of knowledge 


\section{Development of Open Innovation}

\subsection{Important References in Open Innovation Study}

Firstly, references of papers in the dataset were analyzed by CiteSpace II, top 1\% papers every year in the dataset were selected out for analysis. With the help of CiteSpace II, the top 5 cited references can be found according to their frequency of being cited. The book "Open Innovation: The new imperative for creating and profiting from technology" written by Henry Chesbrough in 2003 is the most important one now. In this book, Henry Chesbrough firstly proposed the item "Open innovation" formally and gave out cases indicating the power of open innovation. The existence of the second one "Absorptive Capacity: A New Perspective on Learning and Innovation" supports the idea that study and practice of open innovation were common in the past even though the item did not appear and studies and practices were not systematic.

Table 1. Top 5 cited references

\begin{tabular}{|c|c|c|c|c|c|}
\hline Freq & Centrality & Author & Year & Title & Source \\
\hline 92 & 0.09 & Chesbrough H.W. & 2003 & $\begin{array}{l}\text { Open Innovation: The new imperative } \\
\text { for creating and profiting from } \\
\text { technology }\end{array}$ & $\begin{array}{l}\text { OPEN } \\
\text { INNOVATI } \\
\text { ON NEW }\end{array}$ \\
\hline 57 & 0.06 & COHEN WM & 1990 & $\begin{array}{l}\text { Absorptive Capacity: A New } \\
\text { Perspective on Learning and Innovation }\end{array}$ & $\begin{array}{l}\text { ADMIN } \\
\text { SCI } \\
\text { QUART }\end{array}$ \\
\hline 49 & 0.07 & von Hippel E & 2003 & $\begin{array}{l}\text { Open Source Software and the } \\
\text { "Private-Collective" Innovation Model: } \\
\text { Issues for Organization Science }\end{array}$ & $\begin{array}{l}\text { ORGAN } \\
\text { SCI }\end{array}$ \\
\hline 36 & 0.04 & Lerner J & 2002 & $\begin{array}{l}\text { Lerner, J. (2002) When Bureaucrats } \\
\text { Meet Entrepreneurs: The Design of } \\
\text { Effective 'Public Venture Capital' } \\
\text { Programmes, Economic Journal } 112 \\
\text { (February): F73-F84. }\end{array}$ & $\begin{array}{l}\mathrm{J} \\
\mathrm{ECON}\end{array}$ \\
\hline 35 & 0.01 & Chesbrough Henry & 2006 & $\begin{array}{l}\text { Open Innovation. Researching a New } \\
\text { Paradigm }\end{array}$ & $\begin{array}{l}\text { OPEN } \\
\text { INNOVATI } \\
\text { ON RES }\end{array}$ \\
\hline
\end{tabular}

Another important character is that these references which were cited most are the ones which enjoy highest centralities. Centrality is an indicator given out by CiteSpace II, showing the ability of one reference to link other ones up. Generally, references with high centrality are the ones which combine papers together in this field. Noticing that "Open Innovation: The new imperative for creating and profiting from technology" is the open work for open innovation, the high centrality of it indicates open innovation study is still focusing on the topics Henry Chesbrough proposed in its open work. Most others offer the same result. However, the second one published by Cohen WM also enjoys a high centrality. This shows that open innovation study now are paying attention to past study on relative topics.

Figure 5 shows the whole distribution of all the references analyzed by CiteSpace II, from which we can know most references about open innovation are combined together. This is a character on the early stage of a field's development. At this stage, most studies focus on the topics proposed by the several first papers and they have not gone deeply into a branch of open innovation. The points located far from the only big one in center in figure 5 are ones that are in different fields or even different subjects. So we can just focus on the big one in the center (Figure 6). All the papers are linked to each other very tightly which also confirms open innovation study is still at an early stage. 


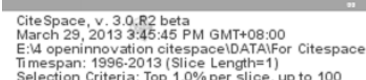
Selection Criteria: Top $1.0 \%$ per slice, up to 10
Network: $N=436, E=3764$ (Density $=0.0397$ )

\section{.}

Figure 5. The whole distribution of references

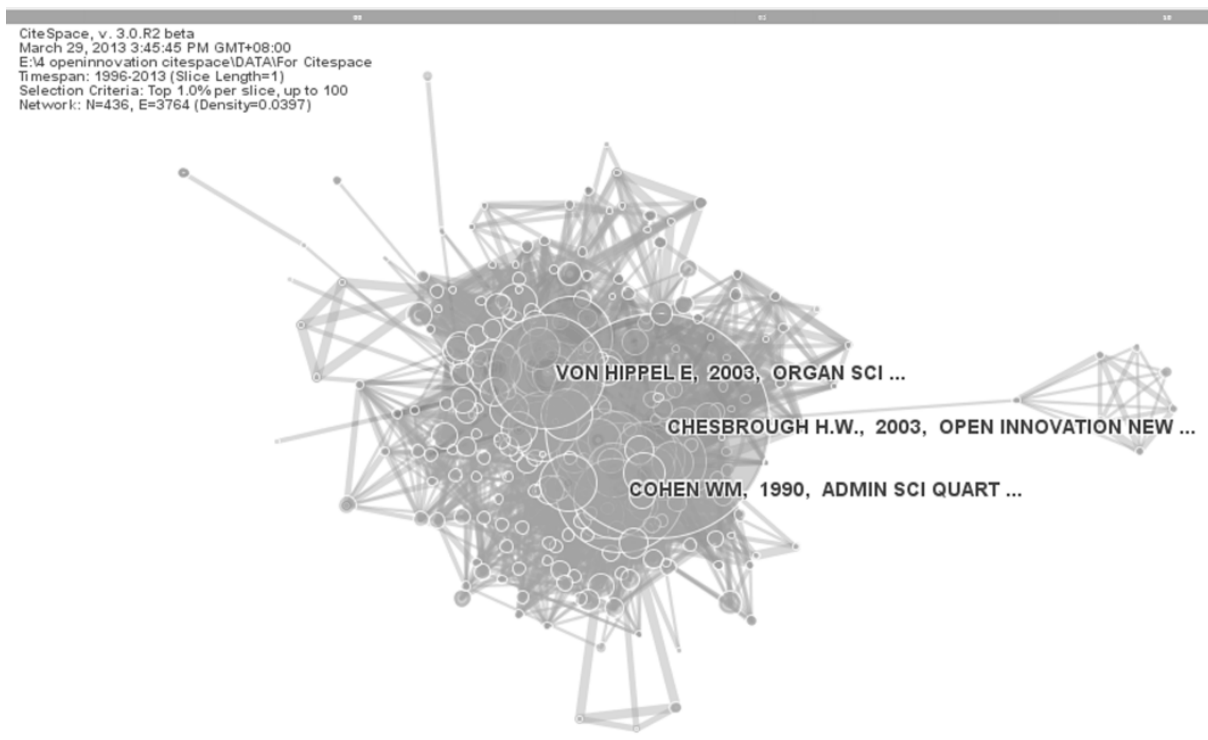

Figure 6. Map of open innovation references

Then from the timeline mode we can see that open innovation references can come back to very early years (figure 7). And references before Henry Chesbrough are well combined with ones after his foundational work. Then we focus on original work of some clusters in Figure 8 which contribute to open innovation these years. Joseph Schumpeter firstly focused on the function of innovation on economy and social change. At first, he focused mostly on individual entrepreneurs as driving force for innovation. After that, he also confirmed innovation in large firms was important. Schumpeter published his "Theory of Economic Development" in 1912 in Germen and a revised edition in English in 1934 to show his main thoughts about innovation. This reference is the origination of innovation which certainly play important role in proposing open innovation. Herbert Simon published his work "The Architecture of complexity" in "Proceedings of the American Philosophical Society". He proposed the general system theory which was abstracted from properties peculiar to physical, biological, or social systems and would be used to all of them. With his theory, a lot of studies can be done for innovation. Mark Granovetter proposed the theory about weak ties in "The Strength of Weak Ties" in the journal "American Journal of Sociology" in 1973. He suggested that it is people with whom we have weak ties can bring us much 
more benefits. His theory has great impact on social study. The thought of him can certainly support main idea of open innovation. Barney Glaser and Anselm Strauss proposed Grounded Theory which worked as an important method in social study. They published "The Discovery of Grounded Theory: Strategies for Qualitative Research" in 1967. This also provides tools for study of open innovation.

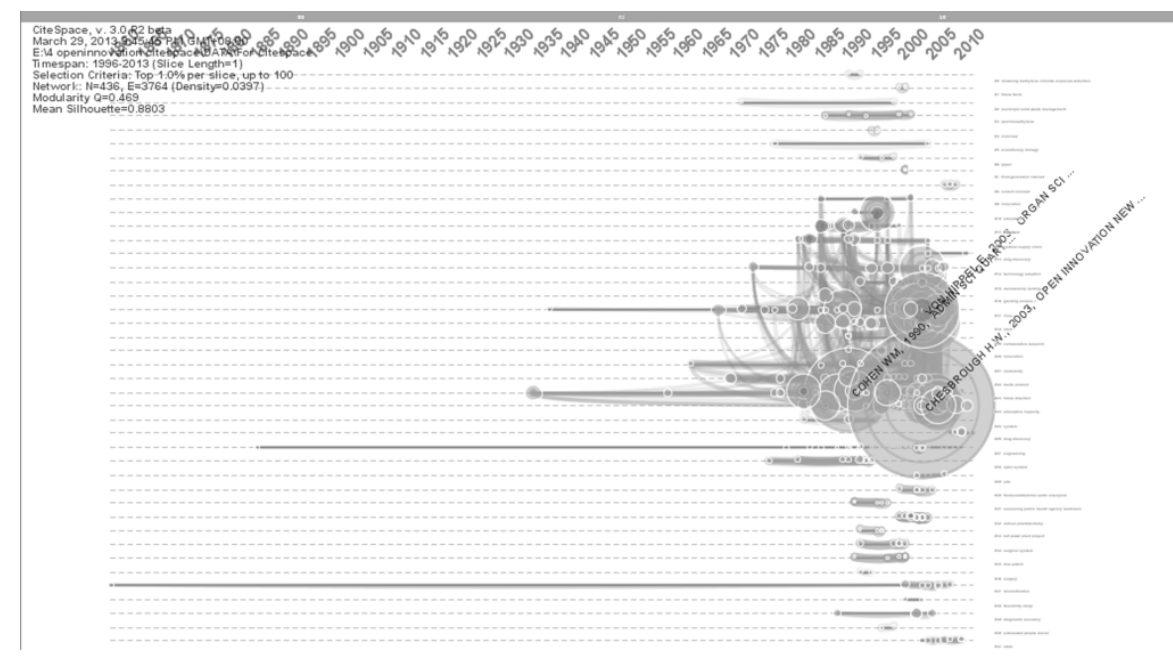

Figure 7. Timeline mode of references

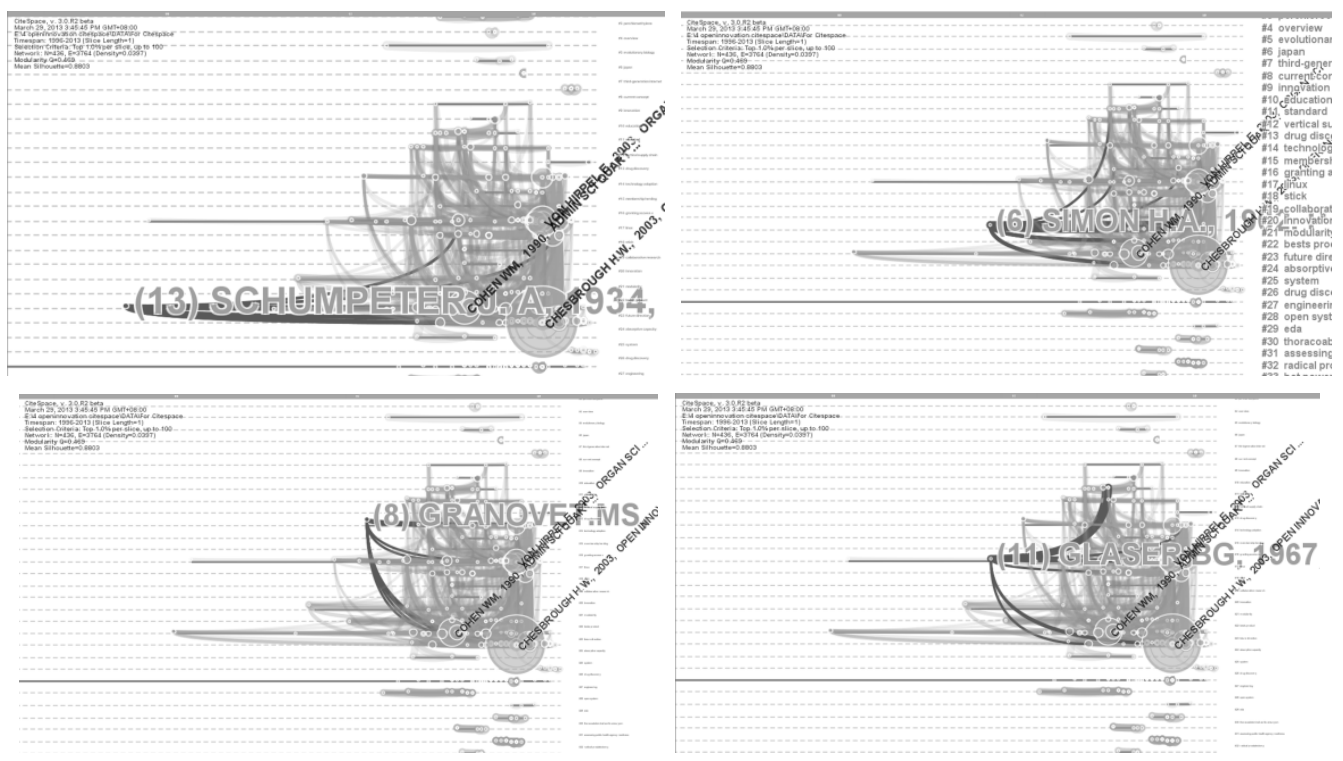

Figure 8. Important references in early years 


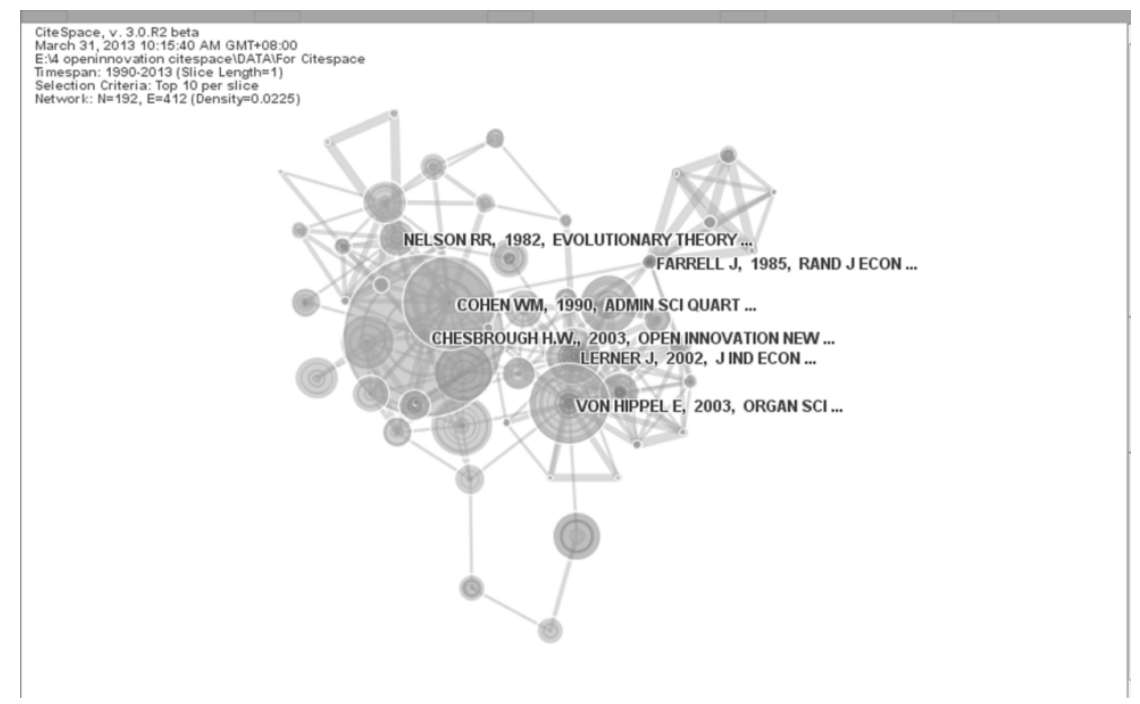

Figure 9. Map of open innovation references (top 10 for each slice)

At last, in order to see the map more clearly, we chose to work on top 10 cited references for each slice (figure 9) which enjoys the same structure as figure 6 .

\subsection{Main Authors for Open Innovation Study}

We list the top 10 authors according to both their numbers in the dataset (Table 2) with help from Web of Science and how many times they were cited (Table 3) with help from CiteSpace II. In fact, "Chesbrough H.W." and "Chesbrough H" in Table 3 stand for the same author Henry Chesbrough. Then we can conclude that authors who offer enough papers without very radical thought will not obtain enough impact on the whole open innovation study. University of California at San Diego Hamilton Glaucoma Center published many papers related to open innovation. However, they were not really studying open innovation. We can conclude that the dataset from Web of Science excluded many effective papers on open innovation which makes the dataset effectiveness. In fact, Web of Science collects journals in relative science subjects. But to some extent, the most important authors in open innovation are not ones who having huge number of publications.

Table 2. Top 10 authors in dataset according number of papers

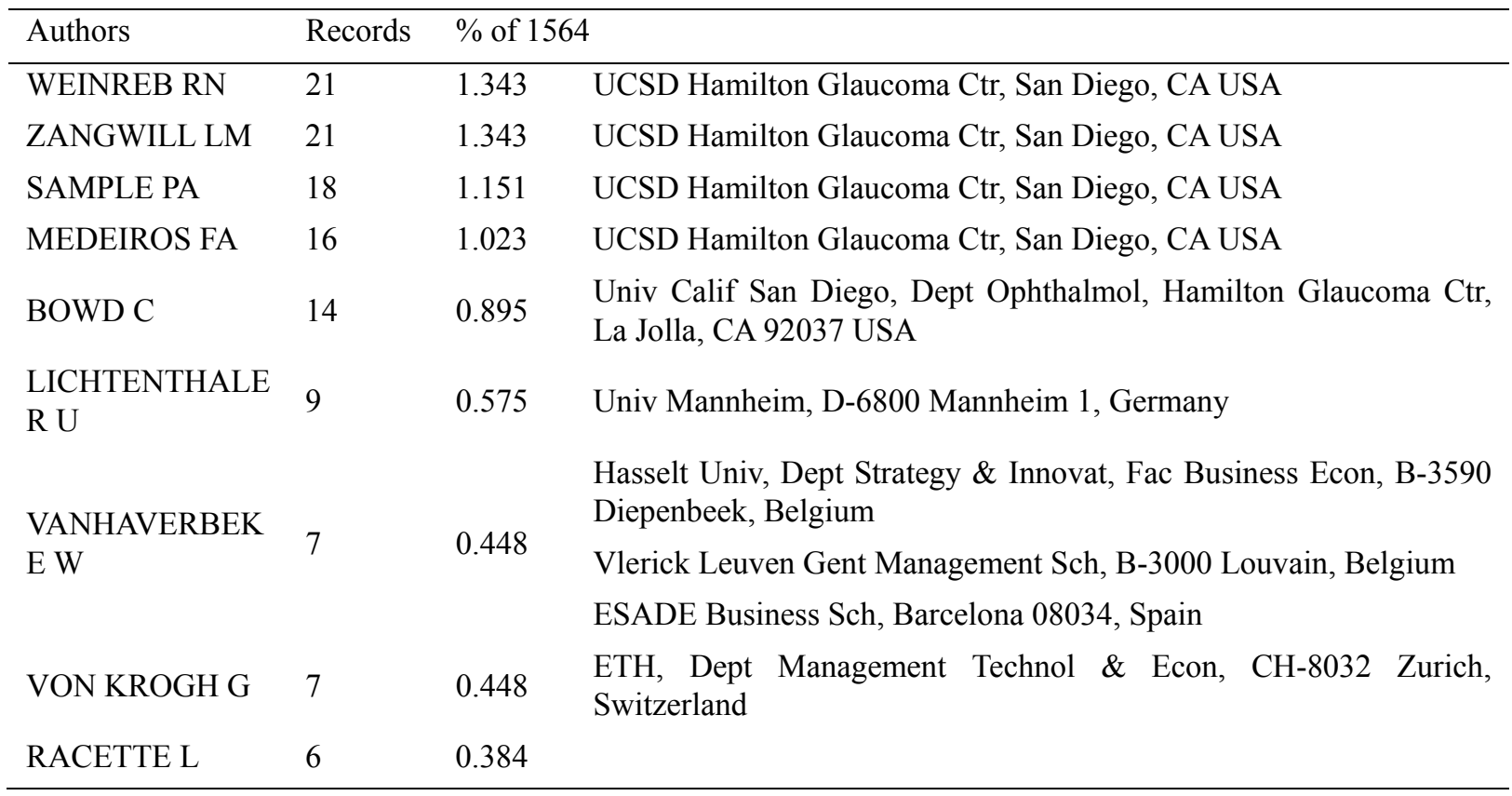


Table 3. Top 10 authors according to cited times

\begin{tabular}{lll}
\hline Freq & Author & Year \\
\hline 92 & Chesbrough H.W. & 2003 \\
72 & von Hippel E & 2003 \\
66 & COHEN WM & 1990 \\
62 & Rogers EM & 1995 \\
56 & Lerner J & 2002 \\
53 & Teece DJ & 2006 \\
47 & Chesbrough H & 2006 \\
43 & EISENHARDT KM & 1988 \\
43 & von Krogh G & 2012 \\
37 & Lakhani KR & 2003 \\
\hline
\end{tabular}

After all, Henry Chesbrough is the most important author now, he created this area. All the important authors with great impact in this field can be divided into two groups considering their publication years. Henry Chesbrough, Von Hippel and other new authors are the ones who opened this open innovation area and proposed essential concepts about it. While authors like Cohen WM and Rogers EM contributed a lot to topics in this field far earlier without the formal term "open innovation". Most of these important authors also have tight links (Figure 10).

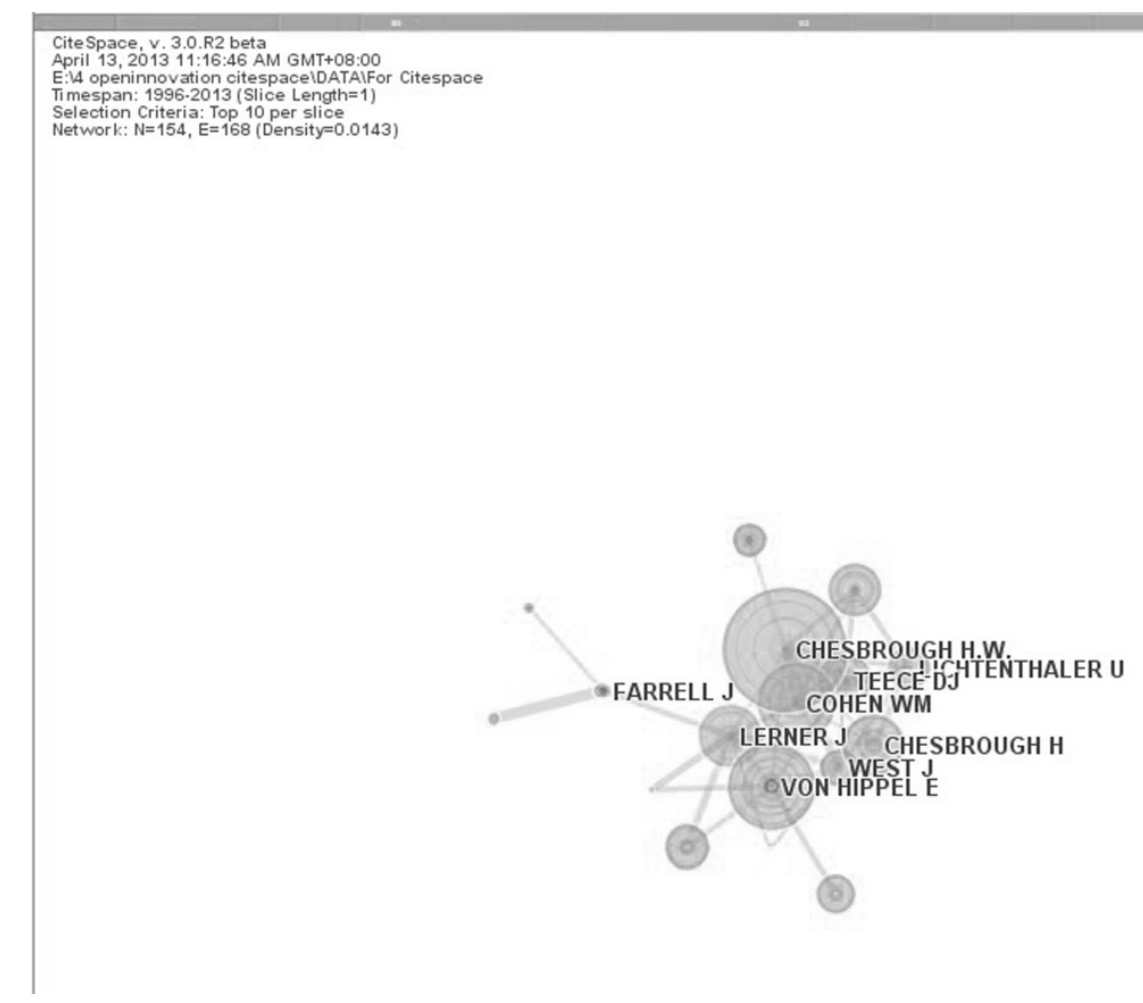

Figure 10. Main authors in open innovation study

\subsection{The Trend of Open Innovation Study in the Past and in the Recent Future}

Firstly, papers in our dataset were studied according to the Web of Science Categories (Table 4). From this result, we believe that thoughts of open innovation have been applied to many fields and paly outstanding role in certain ones (like "computer science information systems" and "surgery"). "Management" ranks firstly in this 
dataset which indicates that general study on open innovation is still prevalent. In this case, open innovation cannot be treated as a mature discipline. However, the ones rank after "Management" are "Engineering industrial", "Operations research management science", "Computer science information systems", "Surgery" and so on. They take much more percentages than "Management" in this dataset which reveals that open innovation has already been used to some relative fields. From this situation, we can know that open innovation obtains some useful theories and accumulates some knowledge but still needs further study to answer most questions about it.

Table 4. Top 10 web of science categories in dataset

\begin{tabular}{lll}
\hline Web of Science Categories. & Number & Percentage of 1564 \\
\hline Management & 230 & 14.706 \\
Engineering industrial & 152 & 9.719 \\
Operations research management science & 144 & 9.207 \\
Computer science information systems & 114 & 7.289 \\
Surgery & 97 & 6.202 \\
Business & 89 & 5.691 \\
Engineering multidisciplinary & 87 & 5.563 \\
Information science library science & 72 & 4.604 \\
Engineering electrical electronic & 66 & 4.22 \\
Environmental sciences & 63 & 4.028 \\
\hline
\end{tabular}

Besides the dataset, we mostly focused on cited references to depict trends of open innovation. Key words of cited papers were studied with CiteSpece II. Firstly, top 10\% and used 1-year slices was chosen and threshold was made be 100. Based on this, we listed top 20 cited keywords in period 1990 to 2013 (Table 5) and in period 2010 to 2013 (Table 6). Combine the two lists, we can easily find that the key word "research-and-development" exceeded "management" and "model" and ranked 5 which shows it became more important these years than before. While "model", "open source software", "evolution" and "diffusion" dropped down significantly. This phenomenon indicates study of open innovation these days less focus on model study, knowledge diffusion and evolution and software study no longer plays that important role in open innovation. Furthermore, "information" and "surgery" are not in the top 20 key words any more. And "absorptive ability" and "network" took their place. This result means that open innovation study is becoming more and more concentrated on its own area instead of surgery. Two important topics are showing up. They are absorptive ability of organizations in open innovation environment and network which is critical for success of open innovation. 
Table 5. Top 20 key words in period 1990-2013

\begin{tabular}{lllll}
\hline & Freq & Centrality & Keyword & Year \\
\hline 1 & 231 & 0.19 & innovation & 1997 \\
2 & 113 & 0.03 & open innovation & 2008 \\
3 & 83 & 0.1 & performance & 2002 \\
4 & 69 & 0.08 & model & 1997 \\
5 & 65 & 0.06 & technology & 2001 \\
6 & 58 & 0.17 & management & 2000 \\
7 & 50 & 0.04 & research-and-development & 2003 \\
8 & 50 & 0.06 & open source software & 2006 \\
9 & 48 & 0.02 & industry & 2007 \\
10 & 48 & 0.04 & systems & 1998 \\
11 & 42 & 0.07 & design & 2005 \\
12 & 41 & 0.04 & product development & 2008 \\
13 & 40 & 0.11 & knowledge & 2004 \\
14 & 37 & 0.07 & diffusion & 1997 \\
15 & 36 & 0.02 & evolution & 2002 \\
16 & 30 & 0.08 & surgery & 2000 \\
17 & 30 & 0.16 & information & 2001 \\
18 & 29 & 0 & firms & 2007 \\
19 & 29 & 0.05 & perspective & 2006 \\
20 & 29 & 0.1 & impact & 2009 \\
\hline
\end{tabular}

Table 6. Top 20 key words in period 2010-2013

\begin{tabular}{lllll}
\hline & Freq & Centrality & Keyword & Year \\
\hline 1 & 107 & 0.38 & innovation & 2010 \\
2 & 90 & 0.12 & open innovation & 2010 \\
3 & 50 & 0.07 & performance & 2010 \\
4 & 42 & 0.07 & technology & 2010 \\
5 & 38 & 0.06 & research-and-development & 2010 \\
6 & 34 & 0.11 & model & 2010 \\
7 & 30 & 0.07 & management & 2010 \\
8 & 28 & 0.03 & industry & 2010 \\
9 & 26 & 0.08 & product development & 2010 \\
10 & 25 & 0.08 & systems & 2011 \\
11 & 24 & 0.15 & open source software & 2010 \\
12 & 23 & 0.01 & design & 2010 \\
13 & 22 & 0.06 & knowledge & 2011 \\
14 & 20 & 0.03 & absorptive-capacity & 2010 \\
15 & 19 & 0.06 & firms & 2010 \\
16 & 18 & 0 & perspective & 2010 \\
17 & 17 & 0.09 & impact & 2012 \\
18 & 17 & 0.06 & networks & 2010 \\
19 & 16 & 0 & evolution & 2012 \\
20 & 16 & 0.03 & diffusion & 2010 \\
\hline
\end{tabular}




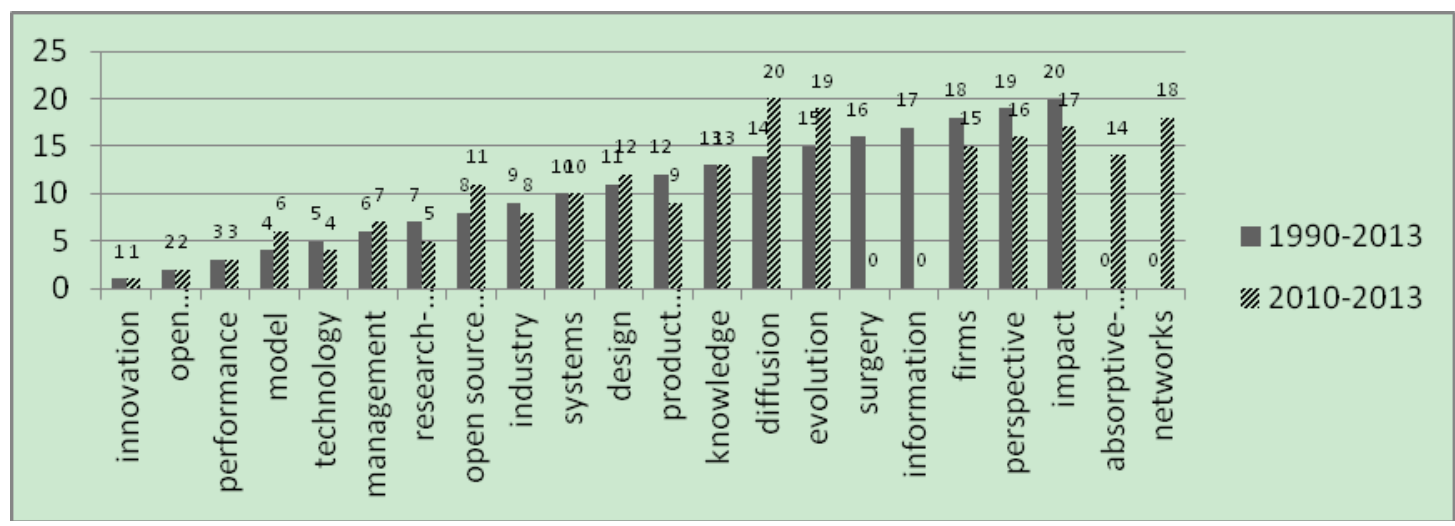

Figure 11. Change of key words in rank

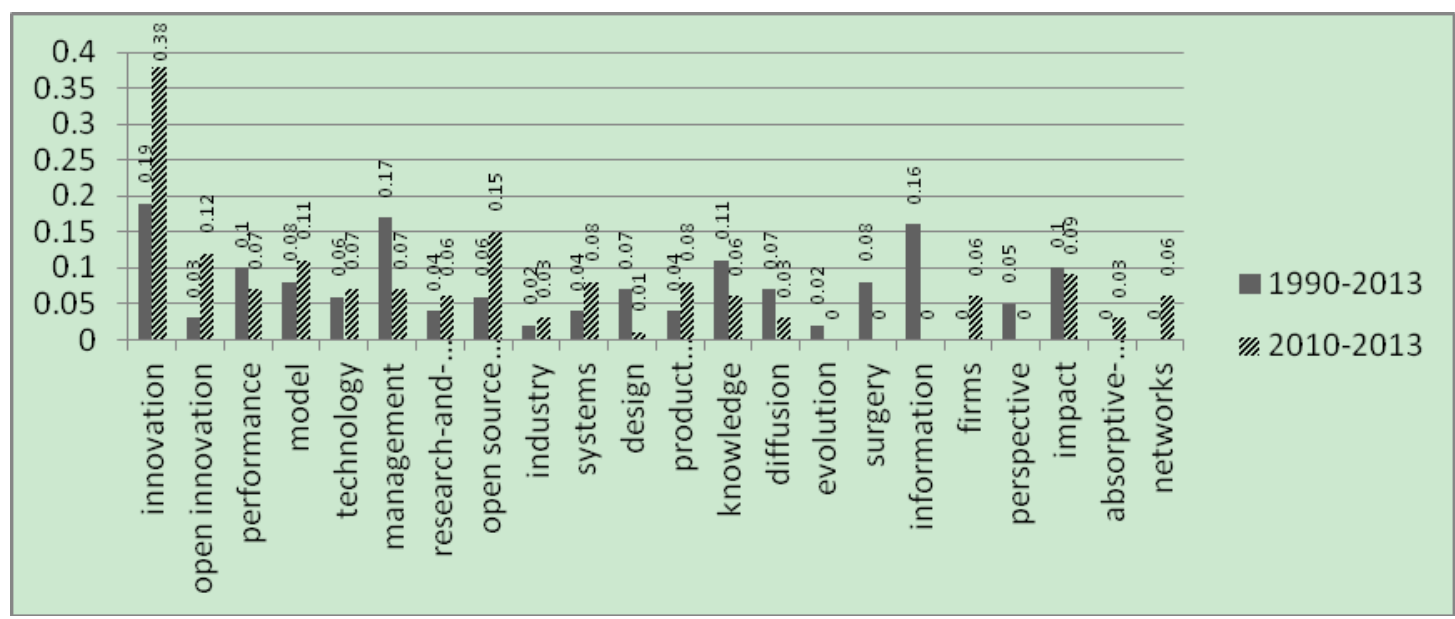

Figure 12. Change of key words in centrality

According to figure 13 all the keywords about open innovation linked tightly which also means this is a relative new field and all topics have some relationship with each other. According to the timeline mode of these key words, open innovation developed from a distinct road (Figure 14). Firstly, "model", "diffusion" and "innovation" provides basic ideas for development of open innovation. After that, the perspective of system plays an important role. Then it comes to "internet" and "management". People became focus on technology, information and performance of organizations. "Research and development" is also an important topic for open innovation study. Then with all these keywords, open innovation was formally proposed in 2003. After this item, researchers study further on "evolution", "knowledge", "design", "open source software", "perspective", "industry", "product development", "impact", "absorptive ability" and "network".

In order to see structure of these keywords more clearly, we marked clusters worked out by CiteSpace II (Figure 15) and reset to pick out top 30 (Figure 16) and top 5 (Figure 17) in each slice. Obviously, all the clusters are linked to the open innovation cluster which takes the place of the center. And other relative ones about innovation are just beside open innovation, while others like surgery are further from open innovation but also have strong links. At the same time, we can know clearly about relations among the most important topics about open innovation according to maps of cited keywords. Innovation enjoyed systematic studies in the past years then had its huge network in these topics. And these years, open innovation received much more attention. Open innovation was cited greatly these years and "performance", "research and development" and "technology" are all around it directly and tightly. However, open innovation still needs more time to have a systematic network because of its less important and less number of branches. 


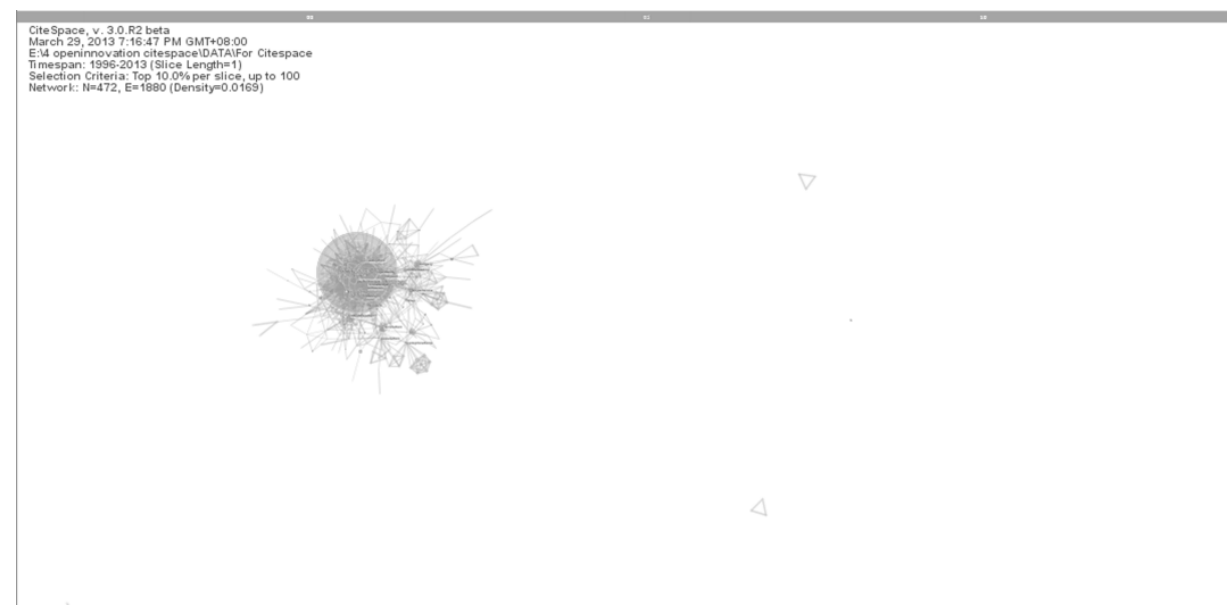

Figure 13. Most cited key words (top 1\% for each slice)

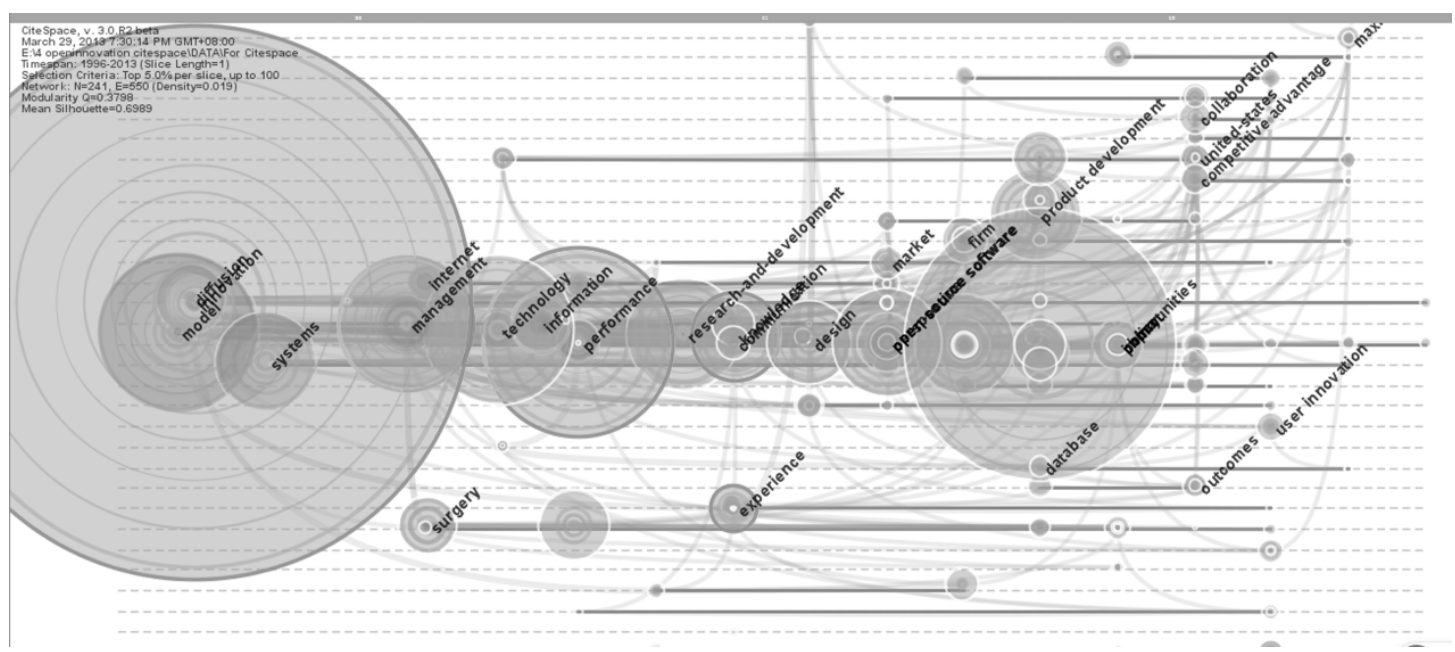

Figure 14. Timeline mode of key words (top 5\% for each slice)

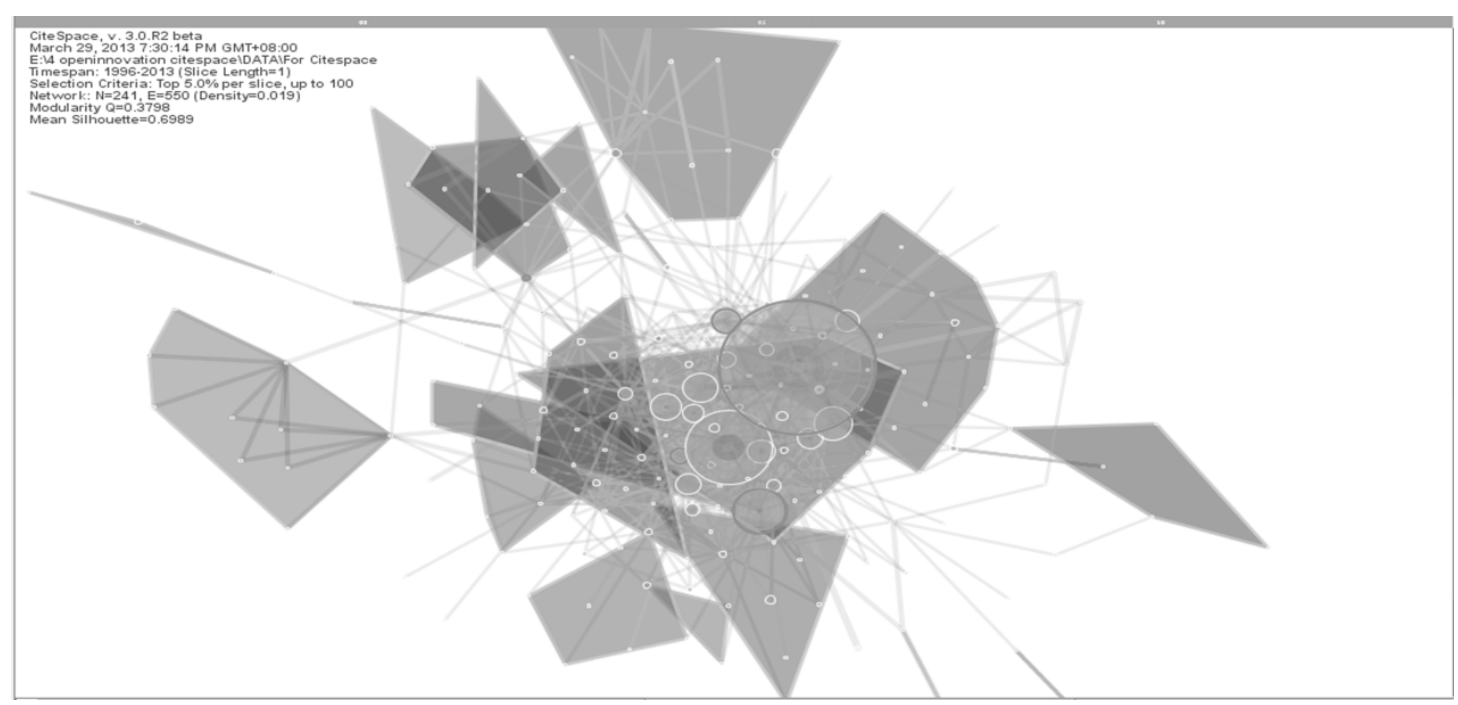

Figure 15. Clusters of key words 


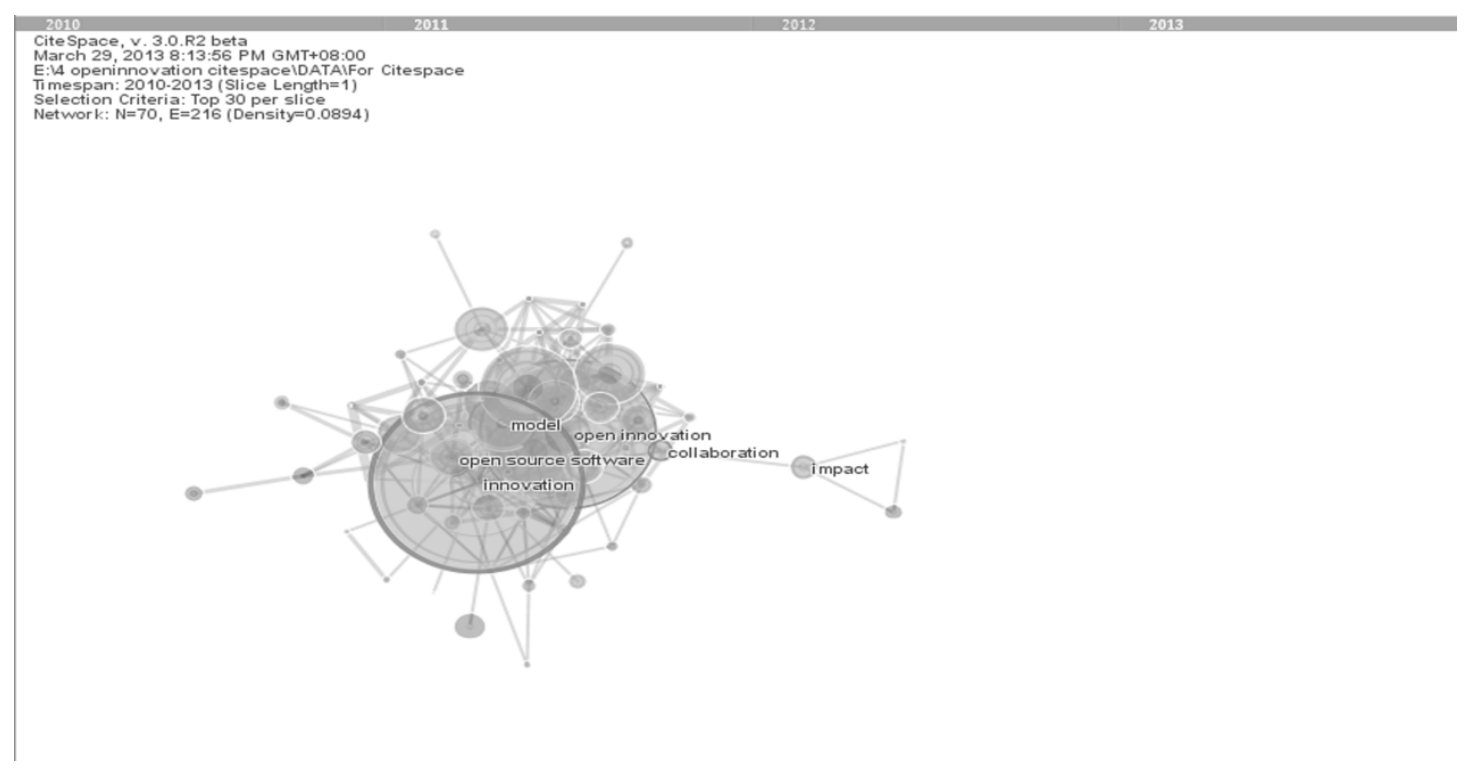

Figure 16. Most cited key words (top 30 for each slice)

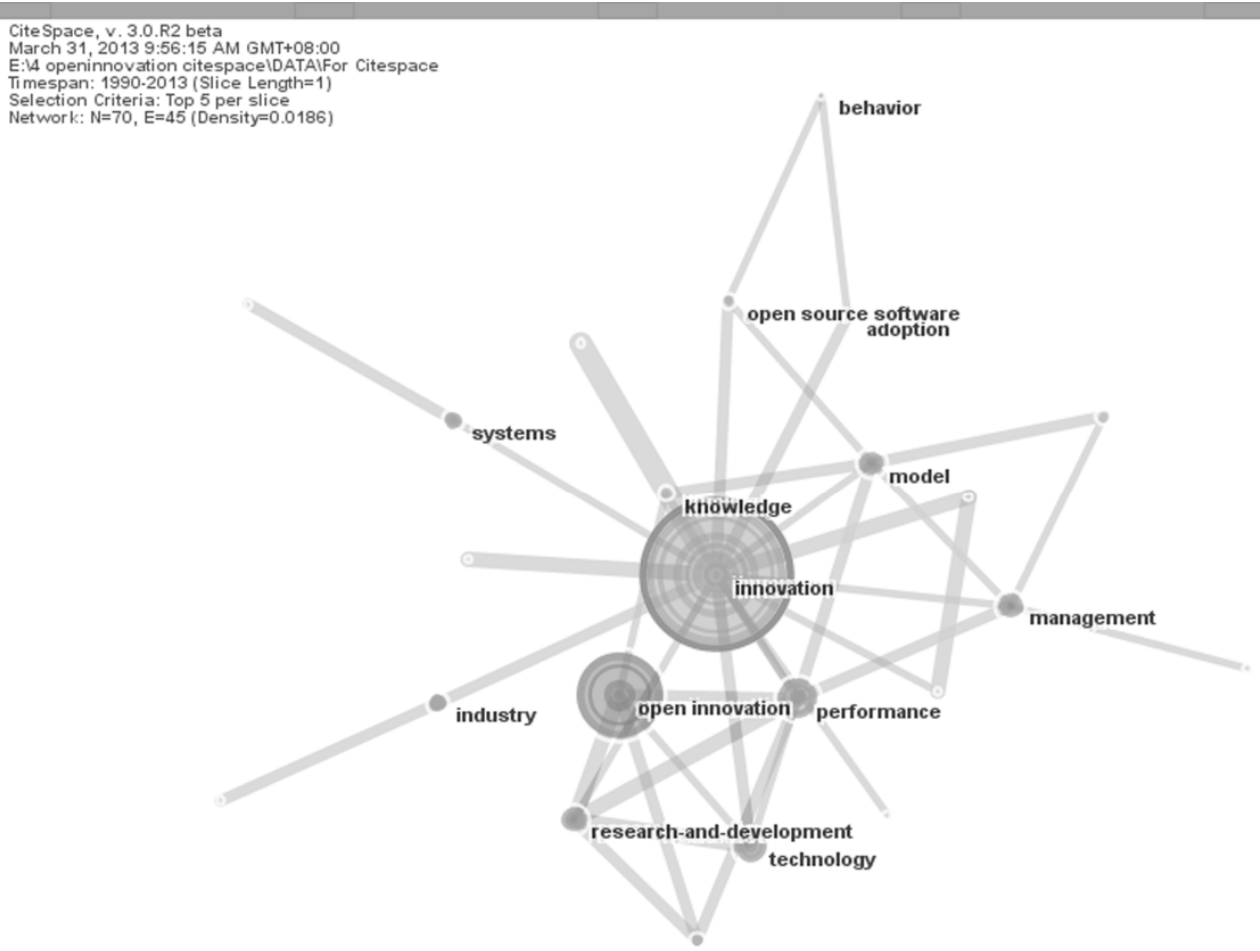

Figure 17. Most cited key words (top 5 for each slice)

\section{Summary of Results}

1) The thoughts of open innovation were existed lots of years ago. Most popular theories in open innovation now have some kinds of links with papers in early time which is the best proof of the existence of these thoughts in those years.

2) We found most important papers on open innovation and they come from ones that were critical in the past. The most important one is "Open Innovation: The new imperative for creating and profiting from technology" 
and then comes "Absorptive Capacity: A New Perspective on Learning and Innovation" and "Open Source Software and the "Private-Collective" Innovation Model: Issues for Organization Science". They are all based on basic knowledge in the past such as "Theory of Economic Development" made by Schumpeter, the general system theory proposed by Herbert Simon, "The Strength of Weak Ties" worked out by Mark Granovetter and Grounded Theory pointed by Barney Glaser and Anselm Strauss.

3) Most important authors in open innovation study were picked out. It was Henry Chesbrough, Von Hippel and other authors shaped open innovation status. And we figure out that some authors in the past are also important in contributing to development of open innovation study, such as Cohen WM and Rogers EM.

4) Study on nature of open innovation is still the most important topics in this field, and people focus on its performance. The top 20 key words in open innovation study recent years are "innovation", "open innovation", "performance", "technology", "research-and-development", "model", "management", "industry", "product development", "systems", "open source software", "design", knowledge", "absorptive-capacity", "firms", "perspective", " impact", "networks", "evolution" and "diffusion".

5) The hot and new topics were found and topics becoming less attractive were also picked out. Among all the top 20 key words, "research-and-development" attracted more attentions while "model", "open source software", "evolution" and "diffusion" dropped down significantly. "Absorptive capacity" and "network" are new ones in this family. And "information" and "surgery" were no longer ranked in top 20. In one word, Researchers pay attention to Research and Development, the ability of absorbing knowledge and networks of firms much more than before.

6) Open innovation was formed directly along a clear road. Figure 14 shows its road map. We can list all the points on this road in a time order: firstly it was "model", "diffusion" and "innovation"; then "internet" and "management"; "technology", "information" and "performance"; "research and development". And with all these keywords, "open innovation" was formally proposed in 2003. After this item, researchers study further on "evolution", "knowledge", "design", “open source software", "perspective", "industry", "product development", "impact", "absorptive ability" and "network".

7) Open innovation is at its early stage. Open innovation study attracts many researchers and organizations. However, it has not systematic theories or knowledge although it really helped some companies to get high profits. At this stage, most studies are still focus on the nature of open innovation itself rather than develop its applicable branches. It must need some more time to find or develop its useful branches for the further contribution to problems in reality.

\section{Conclusion}

This paper analyzed papers and trends in open innovation study which may help to depict the road of open innovation development and also find out all the important and hot topics in this field as well as contribute to further study of open innovation. With the help of Web of Science and CiteSpace II, we picked out the most important references, authors and topics in open innovation study. Tracking the trend of references, we found the origin of open innovation thoughts. Henry Chesbrough who proposed the item "Open Innovation" firstly in 2003 and published many papers about it is treated as the most important author in open innovation. By comparing top 20 key words in period from 1990 to 2013 with top 20 ones in 2010 to 2013, we easily made sure the change of researchers' attentions. With CiteSpace II, figures are worked out to show structure and links of these references, authors and key words, from which we believe that open innovation study is at its early stage and a lot of things can be down in the future about it.

Also, there are some shortcomings in our study. Firstly, the dataset is a misleading one to some extent. Many important journals are excluded. Even though their cited references can describe situations quite well, we lose the opportunity to process target data directly. Besides, figures made by CiteSpace II cannot contain all data because of its computational capability. In this case, minor details will be ignored.

Open innovation is a hot topic nowadays. After Henry Chesbrough's great work, many companies in almost all industries are interested in this fantastic idea about technology management. Open innovation does provide a good way for future development of many organizations. In this condition, it is becoming extremely hot. However, open innovation is at an early stage according to our study. Its nature and application need powerful study to contribute to future innovation and technology management. Based on our work, studying at nature of open innovation will still be the most important task in recent future but finding or developing new branches from open innovation will be an important and long term trend. 


\section{References}

Bianchi, M., Cavaliere, A., Chiaroni, D., Frattini, F., \& Chiesa, V. (2011). Organisational modes for Open Innovation in the bio-pharmaceutical industry: An exploratory analysis. Technovation, 31(1), 22-33. http://dx.doi.org/10.1016/j.technovation.2010.03.002

Chen, C. (2004). Searching for intellectual turning points: Progressive Knowledge Domain Visualization. Proc. Nat. Acad. Sci., 101(Suppl.), 5303-5310. http://dx.doi.org/10.1073/pnas.0307513100

Chen, C. (2006). CiteSpace II: Detecting and visualizing emerging trends and transient patterns in scientific literature. Journal of the American Society for Information Science and Technology, 57(3), 359-377. http://dx.doi.org/10.1002/asi.20317

Cheng, C., \& Huizingh, E. (2010, June 6-9). Open innovation to increase innovation performance: evidence from a large survey. Proceedings of the XXI ISPIM International Conference, Bilbao, Spain.

Chesbrough, H. (2003a). The logic of open innovation: Managing intellectual property. California Management Review, 45(3), 33. http://dx.doi.org/10.2307/41166175

Chesbrough, H. (2003b). Open Innovation: The New Imperative for Creating And Profiting from Technology. Boston, MA: Harvard Business School Press.

Chesbrough, H. (2012). Open Innovation Where We've Been and Where We're Going. Research-Technology Management, 55(4), 20-27. http://dx.doi.org/10.5437/08956308X5504085

Chesbrough, H., Vanhaverbeke, W., \& West, J. (2006). Open Innovation: Researching a New Paradigm. OUP Oxford.

Chesbrough, H., \& Crowther, A. K. (2006). Beyond high tech: early adopters of open innovation in other industries. $R \&$ D Management, 36(3), 229-236. http://dx.doi.org/10.1111/j.1467-9310.2006.00428.x

Christensen, J. F., Olesen, M. H., \& Kjaer, J. S. (2005). The industrial dynamics of Open Innovation-Evidence from the transformation of consumer electronics. Research Policy, 34(10), 1533-1549. http://dx.doi.org/10.1016/j.respol.2005.07.002

Cohen, W. M., \& Levinthal, D. A. (1990). Absorptive capacity: a new perspective on learning and innovation. Administrative Science Quarterly, 35(1), 128-152. Retrieved from http://www.jstor.org/stable/2393553 http://dx.doi.org/10.2307/2393553

Dahlander, L., \& Gann, D. M. (2010). How open is innovation? Research Policy, 39(6), 699-709. http://dx.doi.org/10.1016/j.respol.2010.01.013

di Benedetto, A. (2010). Comment on 'Is open innovation a field of study or a communication barrier to theory development?' Technovation, 30(11-12), 557. http://dx.doi.org/10.1016/j.technovation.2010.09.005

Gassmann, O., \& Enkel, E. (2004). Towards a Theory of Open Innovation: Three Core Process Archetypes. In: Paper presented at R\&D Management Conference, Lisbon.

Gassmann, O., Sandmeier, P., \& Wecht, C. H. (2006). Extreme customer innovation in the front-end: learning from a new software paradigm. International Journal of Technology Management, 33(1), 46-66. http://dx.doi.org/10.1504/IJTM.2006.008191

Gassmann, O. (2006). Opening up the innovation process: towards an agenda. $R \& D$ Management, 36(3), 223-228. http://dx.doi.org/10.1111/j.1467-9310.2006.00437.x

Harison, E., \& Koski, H. (2010). Applying open innovation in business strategies-evidence from Finnish Software Firms. Research Policy, 39, 351-359. http://dx.doi.org/10.1016/j.respol.2010.01.008

Huizingh, E. (2011). Open innovation: State of the art and future perspectives. Technovation, 31(1), 2-9. http://dx.doi.org/10.1016/j.technovation.2010.10.002

Keupp, M. M., \& Gassmann, O. (2009). Determinants and archetype users of open innovation. $R$ \& $D$ Management, 39(4), 331-341. http://dx.doi.org/10.1111/j.1467-9310.2009.00563.x

Laursen, K., \& Salter, A. (2006). Open for innovation: The role of openness in explaining innovation performance among UK manufacturing firms. Strategic Management Journal, 27(2), 131-150. http://dx.doi.org/10.1002/smj.507

Lee, G., \& Xia, W. D. (2010). Toward Agile: an Integrated Analysis of Quantitative and Qualitative Field Data on Software Development Agility. Mis Quarterly, 34(1), 87-114. 
Lichtenthaler, U. (2007). The drivers of technology licensing: an industry comparison. California Management Review, 49, 67-89. http://dx.doi.org/10.2307/41166406

Lichtenthaler, U. (2008a). Integrated roadmaps for open innovation. Research-Technology Management, 51(3), 45-49.

Lichtenthaler, U. (2008b). Relative capacity: Retaining knowledge outside a firm's boundaries. Journal of $\begin{array}{llll}\text { Engineering and Technology 200-212. } & \text { Management, }\end{array}$ http://dx.doi.org/10.1016/j.jengtecman.2008.07.001

Lichtenthaler, U., \& Ernst, H. (2009). Opening up the innovation process: the role of technology aggressiveness. $R \& D$ Management, 39(1), 38-54. http://dx.doi.org/10.1111/j.1467-9310.2008.00522.x

Lichtenthaler, U., \& Lichtenthaler, E. (2009). A capability-based framework for open innovation: complementing absorptive capacity. Journal of Management Studies, 46 (8), 1315-1338. http://dx.doi.org/10.1111/j.1467-6486.2009.00854.x

Linstone, H. A. (2010). Comment on 'Is open innovation a field of study or a communication barrier to theory development?' Technovation, 30(11-12), 556. http://dx.doi.org/10.1016/j.technovation.2010.09.004

Mowery, D. C. (2009). Plus ca change: Industrial RD in the third industrial revolution. Industrial and Corporate Change, 18(1), 1-50. http://dx.doi.org/10.1093/icc/dtn049

Nagaoka, S., \& Kwon, H. U. (2006). The incidence of cross-licensing: a theory and new evidence on the firm and contract level determinants. Research Policy, 35, 1347-1361. http://dx.doi.org/10.1016/j.respol.2006.05.007

Rigby, D., \& Zook, C. (2002). Open-market innovation. Harvard Business Review, 80-89(10).

Spithoven, A., Clarysse, B., \& Knockaert, M. (2010). Building absorptive capacity to organise inbound open innovation in traditional industries. Technovation, 30(2), 130-141. http://dx.doi.org/10.1016/j.technovation.2009.08.004

Spithoven, A., Clarysse, B., \& Knockaert, M. (2011). Building absorptive capacity to organise inbound open $\begin{array}{llll}\text { innovation in traditional industries. Technovation, } & 31(1), & 10-21 .\end{array}$ http://dx.doi.org/10.1016/j.technovation.2010.10.003

Teece, D. J. (1986). Profiting from technological innovation: implications for integration collaboration, licensing and public policy. Research Policy, 15, 285-305. http://dx.doi.org/10.1016/j.respol.2010.02.010

Terwiesch, C., \& Ulrich, K. T. (2009). Innovation Tournaments: Creating and Selecting Exceptional Opportunities. Harvard Business Review Press.

Tomlinson, P. R. (2010). Co-operative ties and innovation: Some new evidence for UK manufacturing. Research Policy, 39(6), 762-775. http://dx.doi.org/10.1016/j.respol.2010.02.010

van de Vrande, V., de Jong, J. P. J., Vanhaverbeke, W., \& de Rochemont, M. (2009). Open innovation in SMEs: Trends, motives and management challenges. Technovation, 29(6-7), 423-437. http://dx.doi.org/10.1016/j.technovation.2008.10.001

Von Hippel, E. (2005). Democratizing Innovation. Mit Press.

\section{Copyrights}

Copyright for this article is retained by the author(s), with first publication rights granted to the journal.

This is an open-access article distributed under the terms and conditions of the Creative Commons Attribution license (http://creativecommons.org/licenses/by/3.0/). 